\title{
Lateral
}

Journal of the Cultural Studies Association

\section{Crip Collectivity Beyond Neoliberalism in Octavia Butler's Parable of the Sower}

\author{
by Jess Whatcott | Cripistemologies of Crisis: Emergent Knowledges for the \\ Present, Issue 10.1 (Sppring 2021).
}

\begin{abstract}
The importance of Octavia Butler's 1993 novel Parable of the Sower continues to crystalize, as Butler's prescient imagining of urban California torn apart by neoliberal divestment comes to fruition. Following in the space opened up by Black feminist scholarship on Butler, the present essay examines her relevance beyond literary and cultural studies. I argue that Parable is a Black feminist crip theorization of political economy that diagnoses the disabling conditions of precarity under neoliberalism and also prescribes collectivity for crip and mad survival. Neoliberalism describes a global stage of advanced capitalism wherein governments are both incentivized and disciplined into enforcing economic policies that include privatization, deregulation, and market liberalization. As Jodi Melamed defines it, neoliberalism requires a certain kind of political governance, that puts the interests of business over the well-being of people (2011). Neoliberal governance engenders what I call "disabling contradictions," yet the blame for conditions of precarity is deflected onto bodyminds themselves. In Parable of the Sower, Butler theorizes these disabling contradictions of neoliberal governance under advanced capitalism, drawing into focus the political economic systems that cause suffering. Parable also depicts strategies for crip and mad survival that are made possible through the conscious creation of community and networks of solidarity that counter the neoliberal state's devaluation of bodyminds. Gathering to read and discuss the novel, rather than a distraction from the crises, furthers the emergence of crip and mad collectivities. As such, it is an urgent and timely practice for building futures for crip and mad people.
\end{abstract}

KEYWORDS crip, cripistemology, disability, neoliberalism, Octavia Butler, precarity

The importance of Octavia Butler's 1993 novel Parable of the Sower continues to crystalize, as the July 20, 2024 opening date of the novel draws near and Butler's prescient imagining of urban California reshaped by fire seemingly comes true. Standing out among recent scholarship on Butler's writing are Therí Alyce Pickens's and Sami Schalk's evaluations that Butler's novels constitute an essential Black feminist theory of disability and madness. - Following in the space opened up by Pickens's and Schalk's analyses, the present essay also examines Butler's relevance beyond literary and cultural studies. I will argue that Parable is a Black feminist crip theorization of political economy that diagnoses the disabling conditions of precarity under neoliberalism and prescribes collectivity for crip survival.

Neoliberalism describes a global stage of advanced capitalism wherein governments are both incentivized and disciplined by international institutions and multilateral agreements into enforcing economic policies that include privatization, deregulation, and market liberalization. $\stackrel{2}{-}$ As Jodi Melamed defines it, neoliberalism requires a certain kind of 
political governance, through which states rationalize decisions as if they were operating as "businesses whose business is to engineer and manage human, organizational, legal, and natural resources to maximize value and optimize productivity." $\underline{3}$ Such neoliberal governance engenders what I call "disabling contradictions," consisting of, first, reinvigorated eugenicist ideologies designed to remove racialized and gendered threats to the social body. Second, neoliberalism generates new conditions of precarity that are disabling, including the privatization of care for elders, children, and disabled people coinciding with the downward spiral of wages vis-à-vis the cost of living. Deflecting attention from these neoliberal economic policies, the source of crises of precarity are displaced onto racialized, gendered, disabled and mad bodyminds ourselves, depicting us as broken, deviant, and immoral, and thus responsible for our own precarious conditions. $\underline{4}$

In Parable of the Sower, Butler maps these (at the time of her writing, still emergent) disabling contradictions of neoliberal governance under advanced capitalism. Building on Pickens's and Schalk's insights that Butler's work is about Black femme disability because of the centering of Black femme impairment, I argue that Parable of the Sower "cripistemologically" theorizes neoliberal governance..- In examining Parable as "crip" text, I emphasize what the novel theorizes about advanced capitalist neoliberal precarity. Crip theorizations of neoliberalism are also the subject of Robert McRuer's book Crip Times (2018), in which he analyzes dominant representations of disability that have been put to work in buttressing neoliberal austerity, as well as crip cultural productions that exceed neoliberal foreclosures. $\underline{6}$ The present essay turns similarly to representations of disability-in this case fictional-that depict what McRuer (borrowing from José Esteban Muñoz) calls "queer and crip horizons."

As Walidah Imarisha and adrienne maree brown have elaborated, the significance of Butler's work lies not only in her diagnosis of dystopia, but also in her depiction of femme of color survival and thriving. 7 Parable proposes that survival and thriving are made possible through the creation of community and networks of solidarity-akin to what McRuer calls "resistant, radical, pornographic crip sociality" -that exceed the austerity projects of neoliberal agendas. $\stackrel{8}{ }$ Butler's imaginary of "feminist, queer, crip" flourishing (to borrow from Alison Kafer), through the emergence of the collective, serves as a vision of possible life that ruptures the disabling modes of privatization and individual self-sufficiency perpetuated by neoliberal interventions. $\frac{9}{}$

\section{Cripistemologies and Neoliberal Crisis}

In the 2013 special issue of the Journal of Literary and Cultural Disability Studies, Merri Lisa Johnson and Robert McRuer identify cripistemologies as forms of "prohibited knowledge" that emerge out of the experience of disability. 10 Johnson and McRuer's essay contributed to ushering in a critical form of disability studies, joining other work such as earlier issues of Lateral that featured Julie Avril Minich, Jina B. Kim, and Sami Schalk. 11 Johnson and McRuer's contribution to this conversation was to coin "cripistemology," as a way of dismantling the expectation of knowledge from disability "experts," and prioritizing instead the knowledges of those whose bodyminds cannot or will not be cured into normativity. Johnson and McRuer are insistent on taking a capacious view of what experiencing disability means, and consequently who is capable 
of producing knowledge through cripistemological methods; Johnson and McRuer include, importantly, the knowledge gained from being in relation with another who has been disabled.

Decentering the disability expert explodes the conventional disability studies canon. In a section called "Sensational Crips," Johnson and McRuer ground their theory in women of color feminisms and queer theory. $\underline{12}$ What distinguishes expertise on disability (conventional disability studies) from their conceptualization of cripistemology (critical disability studies), is this specific genealogy that insists on reading disability in and through imbrications with gender, sexuality, class, and race. For example, Jina B. Kim imagines a "crip-of-color critique" that links together women of color feminist texts that explore themes of chronic illness (Audre Lorde, Gloria Anzaldúa), with recent disability scholarship that foregrounds race (Jasbir Puar, Therí Pickens), through a coalitional framework of queer of color critique (Cathy Cohen, Rodrick Ferguson).. In In the present study, I pick up on the radical political economy thread within critical disability studies that also marks it as a distinct formation. Just as feminist of color and queer of color theory is grounded in Marxist political economy, Johnson and McRuer's conceptualization indicates that critical disability studies offer a unique critique of formations of capitalism, and specifically the disabling conditions of precarity under neoliberalism. $\underline{14}$

Crips and mad people offer knowledge that emanates from their position as a "surplus" class whose presence threatens the political and economic order. $\underline{15}$ As other scholars have elaborated, society has developed the ideology, since at least the end of the nineteenth century, that bodyminds that carry disease, illness, and impairment are a "menace." 16 This ideology, that I would label as eugenics, promises a future of human perfection through scientifically guided interventions that dispose of diseased, ill, and impaired bodyminds. During the so-called eugenics era of the 1890 s to 1940 s, state and federal policies were implemented in the name of saving the human race and western civilization from rapid degeneration caused by the reproduction of those from so-called defective bloodlines. 17 Eugenics policies, including institutionalization, sterilization, restrictive immigration, and deportation, articulated disabled and mad bodyminds as crises that threatened the imagined future of human perfection. 18 However, these policies fluctuated between contradictory impulses. On the one side, the crisis of tainted bloodlines called for the state-sanctioned neglect and premature death of those inside eugenics institutions, those whose bodyminds could not be made to conform to normative standards of health. On the other side, paradoxically, the state also promised to create perfect human health through experimental treatments, rehabilitation programs, and cures, including reproductive sterilization on the very same bodies that were neglected and exposed to death. $\underline{19}$

The surplus class of disabled and mad bodyminds constructed in the eugenics era programs was gendered and racialized. $\underline{20}$ The sociotechnical imaginary of eugenics conjured a specifically "female" threat, relying for justification on fears of unruly people with uteruses whose reproductive capacity required containment. Eugenics programs had specific effects on people with uteruses including longer recovery from sterilization surgeries like the salpingectomy. The threat of unfit reproduction was grounded in white supremacist fears of race suicide, and eugenics programs capitalized on long-standing legal regimes (including slavery and colonialism) that deny racialized gendered people bodily autonomy. $\underline{21}$ 
When outright eugenics became outmoded following World War II and the stalling of the Great Society in the United States, new modes of governance were introduced that continued to draw on the eugenicist imaginary. These new modes of governance, including policies of privatization, deregulation, and market liberalization, exploded into what Mia Mingus, Eli Clare, and others call "the medical industrial complex." $\underline{22}$ In the medical industrial complex, billions of dollars are funneled into the discovery of new diseases and impairments, while pharmaceutical and technological innovations are promised that can rid society of disease and impairment "once and for all." As an outcome of neoliberalism, the medical industrial complex continued the eugenicist project of locating crisis within disabled and mad bodyminds, and again promised social health could be achieved by curing disease and disability. This theorization of the medical industrial complex maps onto what political theorist Giorgio Agamben names

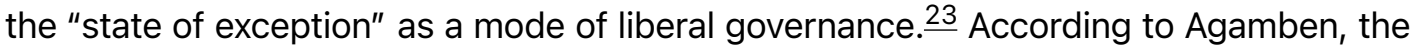
temporality of neoliberalism justifies the permanently temporary suspension of civil liberties. Similarly, the medical industrial complex's rhetoric of crisis and recovery justifies the curtailment of bodily autonomy and reproductive freedom for populations including mad and disabled people, poor and racialized women, and bodyminds with diverse genders.

However, despite the rehabilitative promise, neoliberal policies of deregulation, privatization, and market liberalization are implicated in creating the very conditions of precarity that exacerbate illness, impairment, and mental insecurity. Over the last three decades of the twentieth century, organized government divestment from urban and rural communities that were segregated by race and class from white suburbs left communities of color and poor communities to rely on themselves for access to education, food, and security. The already flimsy social safety net was systematically dismantled through the end of the twentieth century through privatization and disinvestment. At the same time, growing wealth inequality ground down the middle class by pushing all but the super-rich into competition for scarce resources. It was in this context that Butler wrote Parable of the Sower, fictionalizing her portrayal of a multiracial neighborhood forced into extreme self-reliance. The situation has only worsened in the twenty-first century, as the economy rapidly concentrates jobs in lowpaying service and gig industries.

These neoliberal governance policies have a particular impact on disabled and mad people, particularly those who are also racialized and gendered. The process of closing or reducing the size of state psychiatric hospitals and institutions for people classified as intellectually/developmentally disabled beginning the 1960s-known as deinstitutionalization-was one of the first acts of privatization in the neoliberal model in the US. Subsequently, the US has created a bifurcated neoliberal system where the minority, typically white and wealthy, disabled people receive care only through private medical insurance or family members, while many more disabled and mad people of color have been criminalized and warehoused in jails and prisons. Even when public funds are invested in care, the neoliberal state has repeatedly refused to invest in treatments and services that would keep people alive, well, and out of institutions, funneling public money into private industries like nursing homes and to the carceral system rather than directly to sick, disabled, and mad people, or to the programs we want, such as in home support.․ㅡ Preventable deaths of high-profile disability activists, such as Carrie Ann Lucas, attest to the tragic consequences of neoliberal governance, which is focused more on cutting costs than supporting life. 25 How many other lives 
have been cut short due to the combination of conjured crisis, emphasis on cure, organized neglect, and the displacement of blame onto disabled and mad bodyminds?

In addition to what has now become almost routine, systematic, premature death, neoliberalism has increased vulnerability to disaster, especially in the face of capitalisminduced rapid climate change. From supercharged hurricanes to wildfires entering urban spaces, mass death and injury are the consequence, and disabled and mad bodyminds are at increased risk. $\frac{26}{}$ As these disasters show, government aid for communities made vulnerable to disasters through neoliberal economic policy is not a realistic expectation. The rolling power shut-offs orchestrated by Pacific Gas \& Electric company in northern California in the name of preventing wildfires illustrate that neither local or state governments, nor the private companies granted authority over critical infrastructure, take any responsibility for ensuring the safety of disabled and chronically ill people. $\underline{27}$ Further, neoliberal governance absolves the state from blame, pointing the finger on disabled bodyminds ourselves for any suffering and premature death that results from conditions of precarity.

As "situated knowledge" growing out of the experience of precarity, cripistemologies expose how neoliberal governance simultaneously creates and deflects responsibility for disabling conditions. $\frac{28}{2}$ The perspectives of racialized and gendered disabled bodyminds surviving precarity offers distinctive analysis of how the twin violences of cure and neglect operate under neoliberal governance. When cripistemological texts shift attention from the "broken" bodymind to the disabling structure of neoliberalism, they are capable of undermining the urgency within which it is claimed that crises can be solved by state-led, scientifically driven efforts of cure. Resisting the temptation to counter premature death with calls for increased and expanded state interventions, cripistemologies are positioned to theorize the routes to survival and flourishing within and against neoliberalism. Cripistemologies are forms of what Chela Sandoval names as "oppositional knowledges" that can counter the eugenicist sociotechnical imaginaries of the neoliberal state. $\underline{29}$

\section{Parable of the Sower. Cripistemology for Survival and Flourishing}

Octavia Butler's novel Parable of the Sower exemplifies a cripistemological critique of neoliberal governance. Butler has a created a Black femme protagonist with a disabling impairment. Devalued under the terms of neoliberalism due to her impairment, racial status, and gender assignment, this protagonist gains specific knowledge about how to survive disabling precarity. Further, the character critiques the solutions for crisis proffered by neoliberal governance-namely, privatization and deregulation that facilitates medical industrial cure. In Parable, the Black feminist cripistemologist protagonist orchestrates the emergence of a collective that offers a powerful alternative to reliance on the eugenicist solutions of the neoliberal state.

Parable follows Lauren Oya Olamina, a teenager living with her family in a walled-off community near Los Angeles in the year 2024. Outside of the neighborhood walls awaits starvation, rape, sexual exploitation, addiction, and murder. Olamina (as she was called 
by Butler) lives in a neighborhood that has banded together to survive by rigging up security systems, growing food, collecting water, schooling children, and worshipping together at a makeshift church. When Olamina's family is murdered and the neighborhood burned down, she forges a new destiny. She creates a multiracial chosen family that she encourages to walk from Los Angeles to the far northern part of California, with the promise of building a more intentional community on more secluded land.

Olamina has a fictional impairment known as hyperempathy syndrome, which causes her to physically feel the pain or pleasure of any person she can see. Throughout the novel, she experiences the gunshot wounds, sexual violence, and starvation of others she encounters. Layered on top of Olamina's hyperempathy syndrome are symptoms of what might be diagnosed as post-traumatic stress syndrome (PTSD), including symptoms of hypervigilance and insomnia. However, in her context, some of these PTSD symptoms are practical assets. Entering debates about whether Olamina's hyperempathy is a gift or an impairment, Sami Schalk reframes the syndrome as a disability given the specific social, political, and economic context of Olamina's life. $\frac{30}{}$ As Schalk points out, even the ability to share pleasure becomes twisted in the dystopic future that Butler created for Olamina. Olamina suffers from-and, in several terrifying instances, is completely debilitated by-her nervous system's response to witnessing both pain and pleasure.

One reading of the novel might argue that it is a story about crisis, and consequently, that it inhabits the same temporality as neoliberal governance. Indeed, Butler intended for the novel to depict the interlocking crises of the neoliberal present. Butler sought to imagine where "our current behaviors and unintended problems might take us," honing in on patterns in the United States of extreme wealth inequality, the abjection of lowwage and surplus workers, carceral expansion, disinvestment in social resources, and the effects of human-caused climate change. 31 Of interest to the present essay are Butler's additional concerns about pharmaceutical drug abuse and declining access to life-saving medical treatments. Both trends are effects of the neoliberal medical industrial complex that prioritizes profit over life and health-and the latter trend is a specific crisis for Black women.

Olamina's impairment, for example, is caused by her mother's abuse during pregnancy of a fictional drug called Paracetco, so-called "Einstein powder." $\underline{32}$ Mirroring current reallife conditions facing pregnant Black people, in the novel such pharmaceuticals are apparently the only form of medical care readily accessible, while other needs suffer, including maternal health. This racialized and gendered neoliberal contradiction plays out in the text when, after apparently causing hyperempathy syndrome in her child due to drug use, Olamina's mother dies during childbirth. In 1993, when Parable was published, the number of pregnancy-related deaths had already jumped to 11.1 per 100,000 live births from a low of 7.2 in 1987; the number steadily climbed to 17.3 in 2017. 33 Olamina's mother's death represents the specifically racialized dimension of this problem, as non-Hispanic Black women experienced a pregnancy-related mortality rate that was almost three times that of non-Hispanic white women between the years of 2014 and 2017. A participatory research justice study of Black women's maternal health concluded that numerous barriers have been erected that prevent Black women from accessing prenatal care, including "inadequate health insurance coverage," "distrust of and poor treatment by prenatal care providers," "structural inequities" that produce 
stress that contribute to poor health outcomes, and "institutional budget constraints" that prevent providers from offering adequate care. .34 Each of these trends, I argue, can be directly attributed to the ramped up neoliberalization of medical care in the United States over the past thirty years.

Common responses to these disabling conditions are either to cling to the neoliberal promise of recovery through more privatization and deregulation leading to market solutions, or to demand a return of government investment in the social safety net. Parable rejects both the neoliberal and liberal impulses, enacting a cripistemologically grounded critique that emphatically resists the assumption that recovery will come through either more advanced capitalism or state interventions. In the case of market solutions, Butler imagines the return of an indentured servitude in a kind of company town, where able-bodied individuals forfeit their freedom to the corporation in exchange for shelter, food, and protection from outside violence. In this extreme version of privatization, it is as if the state does not exist. Consequently, all human value is reduced to the ability to work, a status that Olamina recognizes as excluding disabled bodyminds like hers.

Butler also reminds us that under neoliberalism, the state is incentivized and disciplined into accelerating its collusion with capital, producing racialized, gendered, and disabled life as "surplus" through routine forms of governance. $\frac{35}{}$ Early in the novel, Butler depicts the election of Charles Morpeth Donner as President of the United States. Exemplifying neoliberal logic by insisting on operating the government like a business, Donner's proposal for restoring the economy and "putting people back to work" is to dismantle labor protections and environmental regulations. $\underline{36}$ Olamina wonders, "And what about those suspended laws? Will it be legal to poison, mutilate, or infect people-as long as you provide them with food, water, and space to die?" 37 Identifying how the disablement of citizens occurs in the name of economic profit, Olamina exposes the fantasy of recovery to something called normal, organized through the mode of neoliberal governance, as a farce and a form of what Lauren Berlant calls "cruel optimism." $\underline{38}$

Yet, exceeding mere critique of the interlocking crises of the neoliberal present, the novel also presents alternative possible futures for those who manage to survive neoliberal catastrophe. One other possible future emerges through collective, community-based emergency planning spearheaded by the visionary foresight of Olamina. Butler's protagonist anticipates the need to prepare materially, psychically, and spiritually for the coming disaster, challenging her parents and other adults who cling to a restoration of normality. Olamina's differences from her family and community, differences which include but are not limited to her impairment and her unorthodox spiritual vision, force her to grapple with the inadequacy of the status quo for her survival.

Olamina's impairment has lent her a pessimistic pragmatism forged through the need to make difficult decisions in order to survive through the bouts of sudden and debilitating pain that her impairment brings. Perhaps it is due to these attributes, gained through impairment, that young Olamina has the ability to push past the fantasy of normalcy in order to forge an alternative plan for survival. While her father and other adults in the community worked to shore up the fences that surround the neighborhood in a desperate bid to maintain the status quo, Olamina secretly assembled an emergency kit, saved cash, and studied edible wild foods. Olamina's preparations ultimately save her 
life after the neighborhood is attacked, and she is forced to flee alone on foot. Olamina's anticipation of the failure of the status quo is cripistemological and serves as a vital model of emergency preparedness for crip collectivities facing neoliberal disasters. This is a form of planning based on the crip of color knowledge that, especially in times of crisis, there may not be any government aid to call upon. Olamina's example is an invitation to pack emergency kits and make collective disaster evacuation plans; to vision with our communities about mutual aid and self-sufficiency; to learn to grow food, harvest wild food, and make medicine; and to craft ethics and principles that can guide our collective decision-making outside and beyond the state. Although categorized under the genre of speculative fiction or science fiction, the text provides an urgent example for developing practical plans to survive the precarious conditions of the neoliberal present.

Powerfully, the novel moves beyond strategizing for crip survival to imagining what Alison Kafer calls "feminist, queer, crip" futures; futures that have until now largely been absent from eugenicist and neoliberal sociotechnical imaginaries. .39 Similarly, the Sins Invalid performing arts collective of queer and trans disabled people of color articulates "disability justice" as a demand for more than the mere survival of disabled and mad people. $\frac{40}{}$ While critique offers the barest minimum necessary for the survival of those devalued under neoliberalism, disability justice also demands a practice of imagining possible futures where queer and trans disabled and mad people of color can "flourish," in Sins Invalid collective member's Patty Berne's terms. $\underline{41}$

Parable imagines possible futures for those who have been disabled and made mad by the precarious conditions of neoliberalism. The novel depicts more than mere crip survival, the story imagines crip flourishing through the emergence of the collective. Once Olamina is forced from her domestic space and left with virtually nothing, she cultivates alternative public arrangements of care and intimacy, building a chosen family and community. Butler provides the following description of this collective emergence:

When Olamina's birth community is destroyed, she begins to build another. She doesn't know at first that that's what she's doing, and she's afraid-terrified-of potentially dangerous strangers. But she learns to reach out in spite of her fear, to choose the best people she can find and bring them together. With her acceptance of Earthseed, she relinquishes hope for supernatural help ... She believes that our only dependable help must come from ourselves and from one another. $\underline{42}$

Family and community are brought together through Olamina's visionary creation of an unorthodox spiritual tradition that she calls Earthseed. Earthseed grows into a multiracial and multigenerational community of people who have been impaired, traumatized, and dispossessed by the catastrophe of neoliberal capitalism and abandoned by the neoliberal state. Together Earthseed as an intentional community defies relegation to tragedy, creating possible futures for themselves through interdependence and mutual aid.

The Earthseed imaginary and the possible futures they create challenge eugenicist strands within neoliberal narratives. As I have discussed, neoliberalism structurally creates disabling conditions through privatization and deregulation, and then continues the eugenicist tradition of displacing responsibility for structural precarity onto surplus 
disabled and mad bodyminds. The Earthseed community resists this process of disablement, by collectively preparing for changing conditions, building capacity to adapt to changing conditions, and indeed, learning how to "shape" inevitable change. Through her depiction of Earthseed, Butler depicts how building collective crip resilience offers a path for surviving within neoliberalist precarity and creating flourishing futures for those that would otherwise be devalued under the neoliberal status quo.

\section{Conclusion: Speculative Fiction and Real-World Collectivity}

I have argued that as a cripistemological fiction, Octavia Butler's 1993 novel Parable of the Sower imagines the possibilities for crip flourishing through collective emergence within and against neoliberal precarity. While this parable about crip life beyond the state is generative, I recognize that it is difficult to imagine how to meet the need for modern technologies to keep disabled and mad people alive outside of the market and state models. Currently, the state seems like the best-although not necessarily the only-way to enforce access and to distribute life-saving services and technologies. $\underline{43}$ It may therefore seem counterintuitive to conclude that a future of crip thriving and flourishing is only possible through a critical perspective of neoliberal modes of state governance. Yet without devoting energies to creating lifesaving services and technologies beyond the state apparatus, disabled and mad people will be stuck in an endless precarious neoliberal loop of crisis, cure, neglect, and scapegoating. The disaster that opens Parable predicts that the neoliberal state is always already imploding under the weight of problems it helped to create, including urban divestment, wealth inequality, and climate change. As the real-life versions of similar disasters have demonstrated, the most acute effect of neoliberal precarity is on racialized communities, on women and gender diverse people within those communities, and on disabled and mad people. $\underline{44}$ The need to think outside the state is not just speculation-racialized and gendered crip communities are always necessarily creating their own terms of survival and developing communities of flourishing beyond the neoliberal state. $\underline{45}$

Such community has emerged among readers of Parable. Readers and scholars of Butler gather digitally, physically, and intellectually, through the creation of such infrastructures as Wildseeds: New Orleans Octavia Butler Emergent Strategy Collective (co-founded by Desiree Evans and Soraya Jean-Louis McElroy), Emergent Strategy Ideation Institute (founded by adrienne maree brown), and the Octavia Butler Legacy Network (founded by Ayana A.H. Jamieson). $\underline{46}$ In these communities, Butler's work is treated as a pedagogical, at times sacred, text containing much needed wisdom about survival, healing, and creating a future where communities of color, women, and gender diverse people can flourish. These communities are an example of the kinds of collective emergence that can be scaled up from the imaginary of speculative fiction into the level of the material world.

If, as I join others in insisting, Butler's fiction is a cripistemological text, then Parable contains knowledge precisely for developing networks of mutual aid through which crip and mad people, specifically, can survive and flourish. .77 Parable offers a critique of neoliberalism, an essential imaginary of "feminist, queer, crip" "flourishing" (in Kafer's 
and Berne's terms), and, finally, operates as a foundation for real-life community building, as Butler's readers and scholars connect digitally and in person. $\underline{48}$ This last is an example of putting speculative fiction as theory into "practice" in a whole new way. Disabled and mad people in the real world currently face the kinds of rapid climate change catastrophe and abandonment by the neoliberal state presciently imagined by Octavia Butler in Parable of the Sower. Collective crip emergence as praxis, facilitated through the gathering of speculative fiction readers, is an urgent and timely practice for realizing futures for crip and mad people.

\section{Notes}

1. Sami Schalk, Bodyminds Reimagined: (Dis)Ability, Race, and Gender in Black Women's Speculative Fiction (Durham: Duke University Press, 2018); Therí A Pickens, Black Madness: Mad Blackness (Durham, N.C.: Duke University Press, 2019).

2. Jodi Melamed, Represent and Destroy: Rationalizing Violence in the New Racial Capitalism (Minneapolis: University of Minnesota Press, 2011).

3. Melamed, Represent and Destroy, 147.

4. Grace Kyungwon Hong, "Neoliberalism," Critical Ethnic Studies 1, no. 1 (Spring 2015).

5. Merri Lisa Johnson and Robert McRuer, "Cripistemologies: Introduction," Journal of Literary \& Cultural Disability Studies 8, no. 2 (July 5, 2014): 127-47.

6. Robert McRuer, Crip Times: Disability, Globalization, and Resistance (New York: New York University Press, 2018).

7. Walidah Imarisha and adrienne maree brown, Octavia's Brood: Science Fiction Stories from Social Justice Movements (Oakland: AK Press, 2015); Walidah Imarisha, "How Science Fiction Can Re-Envision Justice," Bitch Media, February 11, 2015.

8. McRuer, Crip Times: 58 巳

9. Alison Kafer, Feminist, Queer, Crip (Bloomington, IN: Indiana University Press, 2013); Pickens, Black Madness.

10. Johnson and McRuer, "Cripistemologies," 130.

11. Julie Avril Minich, "Enabling Whom? Critical Disability Studies Now," Lateral 5, no. 1 (Spring 2016), https://doi.org/10.25158/L5.1.9 < https://doi.org/10.25158/L5.1.9> ; Samantha Dawn Schalk, "Sami Schalk, 'Critical Disability Studies as Methodology," Lateral 6, no. 1 (Spring 2017).

12. Johnson and McRuer, "Cripistemologies."

13. Audre Lorde, A Burst of Light: Essays (London: Sheba, 1988); Audre Lorde, The Cancer Journals (San Francisco, CA: Aunt Lute Books, 1997); Gloria Anzaldúa, Borderlands: La Frontera, 2nd ed. (San Francisco, CA: Aunt Lute Books, 1999); Cherríe Moraga and Gloria Anzaldúa, eds., This Bridge Called My Back: Writings by Radical Women Of Color, 4th ed. (Albany, NY: SUNY Press, 2015); Jasbir K. Puar, The Right to Maim: Debility, Capacity, Disability (Durham, NC: Duke University Press, 2017); Pickens, Black Madness; Roderick A. Ferguson, Aberrations in Black: Toward a Queer of Color Critique (Minneapolis: University of Minnesota Press, 2004); Cathy J. Cohen, "Punks, Bulldaggers, and Welfare Queens: The Radical Potential of Queer Politics?," GLQ: A Journal of Lesbian and Gay Studies 3, no. 4 (May 1, 1997): 437-65; Kim, "Jina B Kim, "Toward a Crip-of-Color Critique."

14. Johnson and McRuer, "Cripistemologies"; see also Marta Russell, Capitalism \& Disability, ed. Keith Rosenthal (Chicago: Haymarket Books, 2019). 
15. Grace Kyungwon Hong, "Existentially Surplus," GLQ: A Journal of Lesbian \& Gay Studies 18, no. 1 (January 2012): 87-106.

16. Kafer, Feminist, Queer, Crip; Eli Clare, Brilliant Imperfection: Grappling with Cure (Durham: Duke University Press, 2017).

17. Alexandra Stern, Eugenic Nation: Faults and Frontiers of Better Breeding in Modern America (Berkeley: University of California Press, 2005); Paul A. Lombardo, Three Generations, No Imbeciles: Eugenics, the Supreme Court, and Buck v. Bell (Baltimore: Johns Hopkins University Press, 2008).

18. Dorothy E. Roberts, Killing the Black Body: Race, Reproduction, and the Meaning of Liberty (New York: Pantheon Books, 1997); Wendy Kline, Building a Better Race: Gender, Sexuality, and Eugenics from the Turn of the Century to the Baby Boom (Berkeley: University of California Press, 2001); Nancy Ordover, American Eugenics: Race, Queer Anatomy, and the Science of Nationalism (Minneapolis: University of Minnesota Press, 2003); Stern, Eugenic Nation; Paul A. Lombardo, ed., A Century of Eugenics in America: From the Indiana Experiment to the Human Genome Era (Bloomington: Indiana University Press, 2011).

19. Clare, Brilliant Imperfection.

20. Kline, Building a Better Race; Stern, Eugenic Nation.

21. Roberts, Killing the Black Body; Laura Briggs, Reproducing Empire: Race, Sex, Science, and U.S. Imperialism in Puerto Rico (Berkeley: University of California Press, 2002); Natalie Lira and Alexandra Minna Stern, "Mexican Americans and Eugenic Sterilization," Aztlán 39, no. 2 (Fall 2014): 9-34.

22. Mia Mingus, "Medical Industrial Complex Visual," Leaving Evidence (blog), February 6, 2015, https://leavingevidence.wordpress.com/2015/02/06/medical-industrial-complex-visual/ < https://leavingevidence.wordpress.com/2015/02/06/medical-industrial-complex-visual/>; Clare, Brilliant Imperfection.

23. Giorgio Agamben, State of Exception (Chicago: University of Chicago Press, 2005).

24. Liat Ben-Moshe, "Disabling Incarceration: Connecting Disability to Divergent Confinements in the USA," Critical Sociology 39, no. 3 (May 1, 2013): 385-403.

25. Rebecca Cokley, "Carrie Ann Lucas Was a BAMF," Disability Visibility Project, February 27, 2019, https://disabilityvisibilityproject.com/2019/02/26/carrie-ann-lucas-was-a-bamf/ < https://disabilityvisibilityproject.com/2019/02/26/carrie-ann-lucas-was-a-bamf/ $>$.

26. "2 Years After Hurricane Maria Hit Puerto Rico, The Exact Death Toll Remains Unknown," NPR.org, accessed September 27, 2019, https://www.npr.org/2019/09/24/763958799/2-yearsafter-hurricane-maria-hit-puerto-rico-the-exact-death-toll-remains-unkno < https://www.npr.org/2019/09/24/763958799/2-years-after-hurricane-maria-hit-puerto-ricothe-exact-death-toll-remains-unkno>.

27. Vivian Ho, "California Power Shutoff: How PG\&E's Actions Hit the Medically Vulnerable the Hardest," The Guardian, October 11, 2019, https://www.theguardian.com/us-news/2019/oct/11 /california-pge-utility-power-shutoff-disabled < https://www.theguardian.com/us-news/2019 loct/11/california-pge-utility-power-shutoff-disabled>; Matthew Green, "How PG\&E's Power Shutoffs Sparked an East Bay Disability Rights Campaign," KQED, November 6, 2019, https://www.kqed.org/news/11784435/how-pges-power-shutoffs-sparked-an-east-baydisability-rights-campaign < https://www.kqed.org/news/11784435/how-pges-powershutoffs-sparked-an-east-bay-disability-rights-campaign $>$.

28. Donna Haraway, "Situated Knowledges: The Science Question in Feminism and the Privilege of Partial Perspective," Feminist Studies 14, no. 3 (1988): 575-99.

29. Chela Sandoval, Methodology of the Oppressed (Minneapolis, MN, Minneapolis: University of Minnesota Press, 2000). 
30. Schalk, Bodyminds Reimagined.

31. Octavia E. Butler, Parable of the Sower (New York: Grand Central Publishing, 2007), 337.

32. Butler, Parable, 37. 巳

33. U.S. Centers for Disease Control and Prevention, "Pregnancy Mortality Surveillance System," Reproductive Health, November 25, 2020, https://www.cdc.gov/reproductivehealth/maternalmortality/pregnancy-mortality-surveillance-system.htm < https://www.cdc.gov /reproductivehealth/maternal-mortality/pregnancy-mortality-surveillance-system.htm>.

34. Julia Chinyere Oparah et al., "Battling Over Birth: Black Women \& The Maternal Health Care Crisis in California" (Amarillo, TX: Praeclarus Press, 2016). $\_$

35. Hong, "Existentially Surplus."

36. Butler, Parable of the Sower, 27.

37. Butler, Parable of the Sower, 227.

38. Lauren Gail Berlant, Cruel Optimism, E-Duke Books Scholarly Collection (Durham: Duke University Press, 2011).

39. Kafer, Feminist, Queer, Crip.

40. Sins Invalid, Skin, Tooth, and Bone: The Basis of Movement Is Our People: A Disability Justice Primer (self-published, 2016), 15.

41. Sins Invalid, Skin, Tooth, and Bone.

42. Butler, Parable of the Sower, 340.

43. Margaret Talbot, "The Rogue Experimenters," The New Yorker, May 18, 2020, https://www.newyorker.com/magazine/2020/05/25/the-rogue-experimenters < https://www.newyorker.com/magazine/2020/05/25/the-rogue-experimenters $>$..

44. Green, "How PG\&E's."

45. Patty Berne and Vanessa Raditz, "To Survive Climate Catastrophe, Look to Queer and Disabled Folks," Yes! Magazine, July 31, 2019, https://www.yesmagazine.org/opinion/2019/07 31/climate-change-queer-disabled-organizers < https://www.yesmagazine.org/opinion 2019/07/31/climate-change-queer-disabled-organizers $>$.

46. Learn more at www.nolawildseeds.org < http://www.nolawildseeds.org $>$, https://alliedmedia.org/esii < https://alliedmedia.org/esii>, and http://octaviabutlerlegacy.com/ $<$ http://octaviabutlerlegacy.com/>.

47. Therí A. Pickens, "Octavia Butler and the Aesthetics of the Novel," Hypatia 30, no. 1 (2015): 167-80; Schalk, Bodyminds Reimagined.

48. Kafer, Feminist, Queer, Crip.

\section{Author Information}

\section{Jess Whatcott}

Dr. Jess Whatcott (they/them/theirs) is an interdisciplinary American studies scholar working at the intersections of critical disability studies, critical prison 
studies, and queer studies. Dr. Whatcott is Assistant Professor of Women's Studies and an affiliate of LGBTQ+ Studies at San Diego State University. They hold a PhD in politics, with emphases in feminist studies and critical race \& ethnic studies, from University of California Santa Cruz. Their work has been published in Signs: A Journal of Women in Culture and Society, Politics, Groups \& Identities; The Routledge International Handbook of Disability and Sexuality (2021); and Representations of Political Resistance and Emancipation in Science Fiction (2020). They currently organize for abolition in the borderlands of San Diego-Tijuana, occupied Kumeyaay lands.

View all of Jess Whatcott's articles.

\section{Article details}

Jess Whatcott, "Crip Collectivity Beyond Neoliberalism in Octavia Butler's Parable of the Sower," Lateral 10.1 (2021).

https://doi.org/10.25158/L10.1.10

This content is licensed under a Creative Commons Attribution-NonCommercial 4.0 International License. Copyright is retained by authors.

Lateral is the peer-reviewed, open access journal of the Cultural Studies Association.

ISSN 2469-4053 